\title{
Model Influence Of Integrative Themat Learning Against IV Class School Students 'Motivation Private Vocational School, HKBP Pematangsiantar
}

\author{
Asaaro Laia ${ }^{1}$, Yasaratodo Wau ${ }^{2}$ \\ asaarolaia1106@gmail.com ${ }^{1}$, yasaratodo@gmail.com² \\ STKIP Nias Selatan ${ }^{1}$, Dosen Universitas Negeri Medan ${ }^{2}$
}

\begin{abstract}
This research aims to know the influence of learning motivation towards integrative learning thematic grade IV Elementary Private HKBP Pematangsiantar. This research is an ex-post facto research with quantitative approach. The subject of this research grade IV with a sample of 37 students. Sampling techniques using a sample of the total. Research data collection method using question form to thematic learning motivation scale and integrative learning students. Data analysis techniques using simple regression with the help of SPSS program 20. The results showed that: (1) influence of thematic learning integrative in class IV Elementary Private HKBP Pematangsiantar $2016 / 2017$ school year amounted to $62.7 \%$ are high and on the category of $37.3 \%$ are in medium category; (2) the level of motivation of learning at the high percentage of category of $64.4 \%$ and on the category currently amounted to $35.6 \%$; (3) the influence of learning motivation towards integrative thematic Learning students amounted to $22.9 \%$. This can be shown from the value R Square of 0.229 , i.e. there is the influence of the implementation of thematic learning K-13 against integrative motivation learn grade IV Elementary Private HKBP Pematangsiantar
\end{abstract}

Keywords: Integrative Thematic Learning, K-13, Motivation to learn.

\section{Introduction}

The implementation of education is inseparable from the role of the curriculm, the purpose of which is that in it there are goals that are achieved in the curriculum. Nana Syaodih (2007: 4) reveals that the curriculum has a central position in the entire educational process. Based on Law number 20 of 2013 concerning the National Education System, the curriculum is a set of plans and arrangements regarding the purpose, content, and learning materials and the methods used as guidelines for the implementation of learning activities to achieve certain educational goals (Permendikbud No. 67 of 2013). Therefore, in achieving the desired educational goals is very dependent on the curriculum used.

Previously there was a KTSP curriculum in schools, also the 2006 Curriculum and already running, such as overcrowded curriculum content indicated by many subjects and material burdens that exceeded the level of development of the child's age, the competencies needed were not accommodated. Changes to the curriculum are expected to be more in line with the student's level of student development. This is what drives curriculum change. Various problems in implementing the KTSP require the government to make improvements to the curriculum. Based on Minister of Education and Culture Number 67 of 2013, the current 
curriculum in Indonesia is K-13. The implementation of K-13 is a government effort in realizing the achievement of national education goals.

The learning process must be carried out in the form of interactive, innovative, fun, challenging, motivating students, and providing sufficient space for initiatives, creativity, and independence according to the talents, interests, physical and psychological development of students (Permendikbud Number 67 of 2013)

Preliminary data obtained at the HKBP Pematangsiantar Private Primary School found that in the learning process, class I, II, IV, and V teachers used integrated thematic learning. Class II and class IV apply K-13 thematic learning for 3 semesters. The researcher made observations on the learning themes of the Human and Animal Organs. In the learning process most students are enthusiastic when given a Student Worksheet (LKS) by the teacher. The LKS is in the form of a task to group animals into the food pyramid and make food webs. The enthusiasm of students is seen when students often ask questions to the teacher. Although there are still students who look less interested in learning. Before learning begins the teacher asks about the equipment that must be brought by students. In the class, there are penalties agreed upon with the students. If there is a violation, students are asked to make a clipping about learning on that day. At that time there were 4 students who claimed not to carry books and also some equipment. So that in accordance with the agreement of the four students must make clippings, this forms a disciplined attitude and reminds each other between friends. Students also learn to be honest.

Based on the description above, conducted a study in Pematangsiantar HKBP Private Elementary School with the title "The Effect of Integrative Thematic Learning Model on Motivation in Learning Class IV HKBP Private Elementary School Pematangsiantar". in the HKBP Pematangsiantar Private Elementary School 2018/2019 Academic Year

\section{Theoretical Study}

\subsection{Integrative Thematic Learning}

The use of learning approaches that in the learning process can determine learning outcomes. In 2014 the K-13 began to be applied for every level of education and specifically in elementary schools, thematic learning was implemented. The Ministry of Education and Culture stressed that the SD / MI curriculum uses an integrative thematic learning approach from class I to class VI. Integrative thematic learning integrates various competencies from various subjects into one theme, integration is carried out in two ways, namely the integration of attitudes, skills and knowledge in the learning process and the integration of various related basic concepts (Andi Prastowo, 2013: 125, Ministry of Education and Culture (2012: 137),

Thematic learning approach is a learning model that makes learning activities relevant and meaningful. It starts with empowering students' knowledge and experience to help them 
understand and understand their world of life. Based on the Ministry of Education and Culture's K-13 Implementation Training material, (Andi Prastowo 2013: 15) integrated thematic learning functions to provide convenience for students in understanding the material concepts incorporated in the theme and can increase the enthusiasm for learning because the material being studied is material (contextual) and meaningful for students. The characteristics of thematic learning can also be explained in detail as follows: (a) Studentcentered, (b) Providing direct experience, (c) Separation of subjects not so clear, (d) Presenting concepts from various subjects, (e) Flexible , and (f) Using the principle of pleasant learning, Abdul Majid (2014: 89)

The basis of thematic learning is the integration and integration of subject matter into the theme. The implementation of thematic learning must be based on the principles that apply to achieving meaningful and intact learning. There are five principles of integrative thematic learning, namely: (a) Integrative thematic learning has an actual theme, is close to the world of students and exists in everyday life, (b) Integrative thematic learning needs to select material from several subjects that may be interrelated ( b) Integrative thematic learning should not conflict with applicable curriculum objectives, (c) Material that can be integrated into one theme always considers student characteristics such as initial interests, abilities, needs and knowledge, and (d) The combined learning material is not too forced ( Abdul Majid, 2014: 89).

The characteristics of the thematic learning are student-centered, providing direct experience, not so clear separation of subjects, presenting concepts from various subjects, being flexible, using pleasant learning principles, and emphasizing the learning process while doing something.

\subsection{Learning Planning}

Planning good learning is aimed at making the learning process successful. According to Meinbach, Liz Rothlein, \& Anthony D. Fredericks (1995: 9) five important steps in planning successful thematic learning, namely: (a) Selecting Themes, (b) Organizing Themes, (c) Gathering Materials and Sources, (d ) Designing Activities and Tasks, and (e) Carrying Out Learning

The success of integrative thematic learning is largely determined by how the learning is planned and packaged according to the conditions of the students. There are 5 steps in integrative thematic learning planning, namely (1) choosing themes, (2) organizing themes, (3) collecting materials and sources, (4) designing activities and tasks, and the fifth is implementing learning. 


\subsection{Implementation of Integrative Thematic Learning}

\section{a. Preliminary}

The preliminary activity is carried out by the teacher to initiate learning activities. Based on the K-13 mentoring guide (Abdul Majid 2014: 20), preliminary activities include: 1) apperception and motivation, 2) delivery of competencies and learning plans.

b. Core activities

Core activities are the main activities in learning. Abdul Majid (2014: 129) revealed that in core activities, discussions were held on themes and sub-themes through various learning activities using multimethods and media. So that students get a meaningful learning experience. core learning activities that must be carried out by the teacher include: mastery of subject matter, application of educational learning strategies, application of scientific learning approaches (observing, asking, gathering information, associating, communicating), application of integrated / thematic thematic learning, eye-based learning lessons, the use of learning resources / media in learning, the involvement of students in learning and the use of correct and appropriate language in learning.

\section{c. Final Activity / Closing}

It was explained in Permendikbud Number 81 of 2013 that in the closing activities of the teacher along with the students made a summary of the lesson, conducted an assessment or reflection on the activities that had been carried out, provided feedback on the learning process and results, planned follow-up activities in the form of remedial learning, enrichment programs, counseling services and giving assignments both individual and group assignments according to the learning outcomes of students, and delivering learning plans at the next meeting.

\subsection{The Nature and Characteristics of K-13}

The curriculum is all the rules of learning, activities and experiences gained by students under the guidance of the school both in the classroom or outside the classroom. In line with these opinions Caswel and Campbell, 1935 (Nana Syaodih, 2007: 4) revealed that the curriculum consisted of student learning experiences under the guidance of the teacher. Based on Law No. 20 of 2003 concerning the National Education System, the curriculum is a set of plans and arrangements regarding the purpose, content, and material of learning and the methods used to guide the implementation of learning activities to achieve certain educational goals.

While Abdul Majid (2014: 35) suggests 4 elements of change in K-13 which include: 1) graduate competency standards; 2) process standards; 3) standard content; and 4) assessment standards. Graduates' competency standards include the improvement and balance of soft skills and hard skills which include competency aspects of attitudes, skills 
and knowledge. Process standards that were originally focused on exploration, elaboration, and confirmation are complemented by observing, asking questions, reasoning, presenting, deducing and creating. Content standards include the thematic integrative curriculum structure on all subjects, holistic and focused on nature, social and culture, learning is carried out with a scientific approach. Then in the assessment standards include competency-based assessment and authentic assessment (assessment by measuring all competency attitudes, skills and knowledge based on process and results).

Based on the theory above, it can be drawn an outline that the characteristics of K-13 consist of 4 elements of change, namely integrative thematic learning, scientific approach and contestation, and authentic assessment. The application of K-13 is inseparable from the objectives to be achieved. According to Nana Syaodih, (2007: 103) the objectives of the curriculum are formulated based on two things. First is the development of demands, needs and conditions of society. Secondly, it is based on thoughts directed at achieving philosophical values, especially the philosophy of the state. Based on the description above, it can be concluded that the purpose of K-13 is to develop Indonesian human competence in order to be able to live in society, nation and state. The competencies possessed also aim to be able to compete in the global era.

Group A, lessons that provide competency orientation are more cognitive and affective while. Group B, subjects that place more emphasis on affective and psychomotor aspects. In class I, II, and III the basic competencies of science and social science are integrated in accordance with the proximity of the content of the two subjects with content in religious education and character, Pancasila and Citizenship Education, Indonesian Language, mathematics, cultural arts and crafts, and physical education and Sports. For classes IV, V, and VI Basic Competencies of Natural Sciences and Social Sciences stand alone which are then integrated into themes in classes IV, V, and VI.

\subsection{The Nature of Learning Motivation}

Learning motivation plays an important role in increasing passion, pleasure and enthusiasm for learning. Students who have high motivation, then their attention to the learning process is also high.

Learning motivation is important for students. Motivation can awaken the position at the beginning, the process and the final results, informing about the strength of the business of learning. Dimyati and Mudjiono (2006: 85) motivation is also able to direct learning activities, give encouragement, and awareness to divide learning time with other work. Pintrich, 2003 (Schunk et al., 2012: 19) reveals that students who have the motivation to learn tend to spend a lot of effort as learning activities take place, using various strategies that they believe to improve learning, organizing and memorizing information, measuring their understanding, and linking new material with previous experience. 
Based on the above theory it can be concluded that motivation to learn is an encouragement to both external encouragement and internal encouragement that ensures continuity in learning. Continuity in learning can be in the form of enthusiasm in learning, interests or interests of students in the learning process.

\subsection{Forms of Learning Motivation}

According to Syaiful Bahri Djamarah and Aswan Zain (1997: 168) there are 8 forms of motivation that can be used by teachers to maintain students' interest in learning materials. The forms of motivation in question are as follows: (1) Giving numbers, (2) Prizes, (3) Praise, (4) Body Movement, (5) Giving Tasks, (6) Giving a test, (7) Knowing the results, and (8) Punishment. With these penalties students will try to be calm and focus on the learning process. So, the eight sources of motivation above are very important for an educator to increase effectiveness in learning.

\subsection{Factors Affecting Learning Motivation}

Motivation for learning in students can be influenced by many things. Dimyati and Mudjiono (2006: 97) reveal 6 elements that influence learning motivation, namely: (1) Student aspirations or aspirations, (2) Students' abilities, (3) Student conditions, (4) Student environmental conditions, (5) Elements dynamic elements in learning and learning, (6) Teacher's efforts to teach students.

\subsection{Motivation Indicators for Learning in the Implementation of Integrative Thematic Learning}

Indicators of learning motivation according to Hamzah B. Uno (2010: 23) can be classified as follows: (1) the desire and desire to succeed; (2) there is encouragement and need for learning; (3) future hopes and aspirations; (4) appreciation in learning; (5) the existence of interesting activities in learning; (6) the existence of a conducive learning environment, allowing one to learn well.

Schunk, Pintrich and Meece (2012: 17) express 4 motivational indices, namely: (1) Choice of assignments, (2) Business, (3) Persistence, and (4) Achievement. 


\subsection{Research Hypothesis}

There is a significant effect of integrative thematic learning models on Learning Motivation of Class IV Students at HKBP Private Elementary School in Pematangsiantar City.

\section{Research Methods}

This study uses a quantitative research approach, the sampling technique is done randomly. Type of ex-post facto research. that is, research that depends on observing relationships that occur naturally between independent variables and dependent variables. It has happened that researchers began by observing the dependent variable in a study. In ex-post facto research researchers do not need to treat the variables under study. While according to Sugiyono (2010: 14). Gall, M.D, Gall, J.P \& Borg, W.R (2007: 306) Kerlinger, 1986 (Sukardi, 2013: 165). This research was carried out in the HKBP Private Elementary School of Pematangsiantar City that applied K-13. This research was conducted from October to December 2018. The research subjects were fourth grade students in the odd semester of 2018/2019 Academic Year. The object of this research is integrative thematic learning curriculum and student motivation.Population is the whole subject of research, the generalization area consisting of objects / subjects that have certain characteristics and qualities determined by the researcher to be studied and conclusions drawn. In this study all 37 fourth grade students of HKBP Private Elementary School in Pematangsiantar City. Using a total sample because the total population is less than one hundred, the overall population is a sample of research, which is 37 people. (Suharsimi Arikunto (2006: 130,134) Sugiyono (2010: 117,118,126). Using a psychology scale to measure learning motivation and questionnaire (questionnaire) to measure aspects of integrative thematic learning, the technique is by giving respondents written questions to answer (Saifuddin Azwar (2015: $6)$. The instrument of this research uses a Likert scale. Then the rxy value is consulted with $\mathrm{r}$ table, instrument reliability testing, interpreting the acquisition of rh with $\mathrm{rt}$. Data was analyzed with the help of SPSS version 20

\section{Research Results And Discussion}

\subsection{Research Results}

Data on the student learning motivation scale consists of 30 items. The score used is 1 to 4 , so the highest possible score is 120 and the lowest score is 3 . The results of the descriptive analysis of learning motivation variables are obtained the highest score 119; lowest value 71; mean value 93.7; median 95; mode 98 and standard deviation 11.37. Categorizing learning motivation variables can refer to the formula in the table below. 
Table 1. Data Organized

\begin{tabular}{|c|c|c|}
\hline No & Categories & Interval \\
\hline 1 & High & $X \geq \mu+1.0$ \\
\hline 2 & Middle & $\mu-1,0 \leq X<\mu+1,0$ \\
\hline 3 & Low & $X<\mu-1,0$ \\
\hline
\end{tabular}

Information:

$\mathrm{X}=$ Number of scores obtained by students

$=$ Standard deviation

$\mu=$ mean $/$ mean

Based on the average value and standard deviation above, the variables of student learning motivation are presented in the following table:

Table 2. Categories and Percentage of Student Learning Motivation

\begin{tabular}{|l|c|l|l|l|}
\hline No & $\begin{array}{c}\text { Categories } \\
\text { Study } \\
\text { Motivation }\end{array}$ & \multicolumn{1}{|c|}{ Interval } & F & \multicolumn{1}{|c|}{$\%$} \\
\hline 1 & High & $\mathrm{X} \geq 105,07$ & 146 & $62,7 \%$ \\
\hline 2 & Middle & $82,33 \leq X<105,07$ & 87 & $37,3 \%$ \\
\hline 3 & Low & $X<82,33$ & 0 & $0 \%$ \\
\hline \multicolumn{2}{|c|}{ Total } & 233 & $100 \%$ \\
\hline
\end{tabular}

Based on the table, students who have learning motivation. there were 146 students (62.7\%), students who had moderate learning motivation were 87 students (37.3\%), and no students had low learning motivation (0\%). Therefore, it can be concluded that most of the fourth grade students of HKBP SD Pematangsiantar Private Elementary School have high learning motivation.

\subsection{Implementation of K-13 Integrative Thematic Learning}

Data about the K-13 thematic learning implementation questionnaire which was filled by class IV of HKBP City Private Elementary School in the 2016/2017 academic year. The questionnaire consists of 35 items. The score used is 1 to 4 , so the highest possible score is 140 and the lowest score is 35 . The results of the descriptive analysis show that the highest score is 140; lowest score, 75; mean value 111.21; median 111; mode 107 and standard deviation 15.37. These data can be used to categorize learning achievements, according to the formula in the table below. 
Table 2. Data Categorization Formulas

\begin{tabular}{|c|c|l|}
\hline No & Category & \multicolumn{1}{|c|}{ Interval } \\
\hline 1 & High & $X \geq \mu+1.0$ \\
\hline 2 & Middle & $\boldsymbol{u}-1,0 \leq X<\mu+1,0$ \\
\hline 3 & Low & $X<\mu-1,0$ \\
\hline
\end{tabular}

(Source: Saifudin Azwar, 2014: 149)

Based on the known average value and standard deviation and referring to the data categorization formula above, the category of K-13 thematic learning implementation can be seen in the following table:

Table 3. Categories and Percentage of K-13 Integrative Thematic Learning Implementation

\begin{tabular}{|l|c|l|c|c|}
\hline No & Category & \multicolumn{1}{|c|}{$\begin{array}{c}\text { Interval } \\
1\end{array}$} & $\begin{array}{c}\text { f } \\
\text { High }\end{array}$ & $\begin{array}{l}\mathrm{X} \geq 126,58 \\
\mathbf{\%}\end{array}$ \\
\hline 2 & Middle & $95,84 \leq \mathrm{X}<126,58$ & 83 & $64,4 \%$ \\
\hline 3 & Low & $\mathrm{X}<95,84$ & 0 & $35,6 \%$ \\
\hline \multicolumn{2}{|c|}{ Total } & 233 & $100 \%$ \\
\hline
\end{tabular}

Based on the table it can be seen that according to the perceptions of students the implementation of K-13 integrative thematic learning is in the high category, which is $64.4 \%$, the implementation of $\mathrm{K}-13$ integrative thematic learning is in the moderate category of $35.6 \%$, and there is no thematic learning implementation integrative K-13 which is categorized as low. Therefore, it can be concluded that the implementation of K-13 integrative thematic learning according to the perception of fourth grade students of HKBP Private Elementary School in Pematangsiantar City is in the high category. The distribution of data from each category can be seen in the picture below.

\subsection{Prerequisite Test for Analysis}

The normality test is used to find out whether the data distribution is normal or not. In this study the normality test was carried out on both research variables, namely the learning motivation of fourth grade students of SD and K-13 integrative thematic learning. The normality test is carried out with the help of SPSS 21 program. According to Suharsimi Arikunto (2006: 290) the data normality testing criteria of each change variable is if the Chi square value of the calculation is smaller or equal to the Chi Square table, the distribution of data is normally distributed and if Chi Square the count is greater or equal to the price of Chi Squares table $2 \leq \mathrm{t} 2(\chi)$ declared to be abnormally distributed. Based on the calculation that the researcher has done, the following results are obtained. 
Table 4. Results of Normality Test for Learning and Learning Motivation Data. Integrative Thematic K-13

\begin{tabular}{|c|l|c|c|c|}
\hline No & Variables & $\begin{array}{c}\text { Chi- } \\
\text { Square }\end{array}$ & $\begin{array}{c}\text { Asymp. } \\
\text { Sig }\end{array}$ & Ket \\
\hline 1 & $\begin{array}{l}\text { Motivation } \\
\text { Studying }\end{array}$ & 1,98 & 0,738 & Nor-mal \\
\hline 2 & $\begin{array}{l}\text { Thematic } \\
\text { Learning }\end{array}$ & 0,12 & 0,998 & Nor-mal \\
\hline
\end{tabular}

Based on the table above, it can be seen that the Chi squared count on all research variables is smaller than the Chi Square table $(9,488)$ and the significance value is greater than 0.05 , so the data can be said to be normally distributed.

Linearity test is used to determine whether there is a linear relationship between the independent variable and the dependent variable. The second requirement is said to be a linear variable when the calculation shows that the value of $\mathrm{F}_{\text {count }}<\mathrm{F}_{\text {table }}$ with a significance level of 5\%. Linearity testing can be seen in the following table.

Table 5. Linearity Test Results

\begin{tabular}{|cc|c|c|c|c|}
\hline & Var & $\mathbf{F}_{\mathbf{h}}$ & $\mathbf{F}_{\mathbf{t}}$ & Sig & Ket \\
\hline $\mathrm{X} \longrightarrow$ & Y & 0,992 & 1,045 & 0,500 & Linier \\
\hline
\end{tabular}

Information:

X: K-13 Integrative Thematic Learning

Y: Student Learning Motivation

Based on the table above it can be seen that the calculated $\mathrm{F}$ value is 0.992 and the significance value is 0.500 for $\mathrm{X} 1$ against $\mathrm{Y}$. So the calculated $\mathrm{F}$ value in this linearity test is smaller than $\mathrm{F}$ table (1.045) and the significance value is greater than 0.05 , so that it can said the relationship of K-13 integrative thematic learning variables and learning motivation are linear.

\subsection{Hypothesis testing}

The calculation of hypothesis testing uses simple regression analysis using SPSS 21. The hypotheses proposed in this study are as follows. The research hypothesis 'There is an influence between the implementation of K-13 integrative thematic learning on the learning motivation of Grade IV students of Pematangsiantar HKBP Elementary School. R2 value is the amount of influence (effective contribution) between all independent variables on the dependent variable. The amount of R2 produced 0.229 means that $22.9 \%$ of learning motivation variables are influenced by $\mathrm{K}-13$ integrative thematic learning variables while 
the remaining $77.1 \%$ are influenced by other factors. The calculated $F$ value is 68,550 with a significance of 0,000 . Based on the table in appendix 13, the regression equation is made as follows.

$$
\mathrm{Y}=54,357+0,478 \mathrm{X}
$$

The results of the $t$ test in this regression are used to determine the partial effect of each independent variable on the dependent variable. Thematic learning 0.478 if thematic learning increases by increasing by 1 unit then motivation will increase by 0.478 units. Positive influence is shown from the positive beta value of 0.478 . Furthermore, comparing $\mathrm{F}$ count $=68,550>\mathrm{F}$ table $=3,882$ or by comparing the significance value of $0.00<$ level of error $5 \%=0,05$, it can be concluded that integrative thematic learning K-13 has a positive significant effect on student learning motivation.

Based on the testing of the hypothesis above, Ha is accepted. So from the data of this study it can be concluded that the implementation of K-13 integrative thematic learning has a significant effect on the learning motivation of fourth grade students of HKBP Primary School in Pematangsiantar City.

\subsection{Discussion of Research Results}

Statistical analysis on the implementation variables of integrative thematic learning K-13 shows that the percentage of these variables with a high category is $62.7 \%$ and the moderate category is $37.3 \%$. Meanwhile, statistical analysis on the variables of student learning motivation showed that $64.4 \%$ of students had high learning motivation, and $35.6 \%$ had moderate learning motivation.

On testing the hypothesis that has been done the results show that the significance value $=$ $0,000<$ from the error rate of $5 \%=0.05$. These results indicate that the influence of the implementation of K-13 integrative thematic learning has a significant effect on learning motivation of fourth grade students of HKBP Primary School in Pematangsiantar City.

Reviewing the description of the implementation of K-13 integrative thematic learning above that the level of implementation is in the high category at $62.7 \%$ and in the low category at $37.3 \%$. This shows that the level of K-13 implementation especially in integrative thematic learning is quite maximal.

Mulyasa (2014: 68) explains that K-13 can be interpreted as a curriculum concept that emphasizes the development of the ability to perform tasks with their respective abilities, so that the results can be felt by students. In this case, integrative thematic learning is one of the tools in developing students' abilities. As quoted from the Ministry of Education and Culture's K-13 Implementation Training Material (2013: 15) that integrated thematic learning functions to provide convenience for students in understanding the material concepts incorporated in the theme and can increase the spirit of learning because the material being studied is material (contextual) and meaningful for students.

Sardiman (2007: 75) reveals that motivation guarantees continuity of learning activities and gives direction to learning activities, so that the goals expected by the learner can be achieved. Learning motivation plays an important role in increasing passion, pleasure and 
enthusiasm for learning. Reviewing the description of the results of the statistical analysis of learning motivation variables, students have high learning motivation which is equal to 64.4\%. This shows that the level of perseverance, persistence and enthusiasm for learning possessed by students is quite high. This is related to reviewing the description of integrated thematic learning that serves to provide meaningful learning for students to increase enthusiasm in learning. If the implementation of K-13 integrative thematic learning in schools is maximal, the student's learning motivation is also maximal, in other words the implementation of K-13 integrative thematic learning influences students' learning motivation.

Based on this, to determine whether or not the influence of the implementation of integrative thematic learning in 2013 curricula on student learning motivation was carried out hypothesis testing with simple regression analysis. Before testing hypotheses, an analysis prerequisite test was carried out, namely the normality and linearity test. Based on the normality and linearity test that has been done, it can be concluded that the data of this study are normal and linear. Furthermore, as for the calculation results using simple regression analysis the results obtained are that the index of determination $(\mathrm{R} 2)$ which is the magnitude of the influence of K-13 integrative thematic learning variables on the variables of student learning motivation is equal to 0.229 . This figure shows that in this study the implementation of K-13 integrative thematic learning had an effect of $22.9 \%$ on student learning motivation and the remaining $77.1 \%$ was influenced by other factors.

Student learning motivation is not only influenced by the learning process in class, in this case K-13 integrative thematic learning. There are other factors that influence student learning motivation. Dimyati and Mudjiono (2006: 97) revealed 6 factors that influence learning motivation, namely: (1) student aspirations or aspirations, (2) student abilities, (3) student conditions, (4) student environment conditions, (5) dynamic elements in learning and learning, (6) teacher's efforts to teach students. In this case the K-13 integrative thematic learning is included in the teacher's effort factor in teaching students.

Based on this, it can be said that K-13 integrative thematic learning is not an indicator that fully influences student learning motivation. There are other factors that can also affect student learning motivation. Therefore, to be able to increase students' learning motivation, other factors that can influence their learning motivation need to be considered. Encouragement is needed which not only comes from the teacher, but also comes from parents and the surrounding environment. In accordance with the description above, it can be seen the results of hypothesis testing in this study which states that Ha is accepted. Ha received in this study, namely, there is the influence of the implementation of K-13 integrative thematic learning on the learning motivation of fourth grade students of HKBP SD Pematangsiantar Private Elementary School 


\section{Conclusion}

Based on the analysis of the results of the research and discussion, conclusions can be taken as follows:

- The level of implementation of integrative thematic learning K-13 in class IV SDB HKBP Kota Pematangsiantar 2018/2019 Academic Year is 62.7\% in the high category and $37.3 \%$ is in the medium category.

- The level of learning motivation possessed by grade IV SDB HKBP Pematangsiantar Private School 2018/2019 Academic Year in the high category with a percentage of $64.4 \%$ and in the moderate category of $35.6 \%$.

- Effect of the implementation of K-13 integrative thematic learning on student learning motivation by $22.9 \%$. This can be shown from the R Square value of 0.229

\section{References}

[1] Abdul Majid.. Pembelajaran Tematik Terpadu. Bandung: PT Remaja Rosdakarya. (2014)

[2] Andi Prastowo. (Pengembangan Bahan Ajar Tematik. Jogjakarta: Diva Press. 2013).

[3] Dimyati \& Mudjiono. . Belajar dan Pembelajaran. Jakarta: Penerbit Rineka Cipta. (2006)

[4] Gall, M.D, Gall, J.P \& Borg, W.R.. Education Research $\left(8^{\text {th }}\right.$ ed.). United States: Pearson Education. (2007

[5] Hamzah B. Uno. Teori motivasi dan Pengukurannya: Analisis di Bidang Pendidikan. Jakarta : Bumi Aksara, (2010).

[6] Kemendikbud.. Panduan Pendampingan Implementasi K-13. Jakarta: Kemendikbud. (2013)

[6] ____ Materi Pelatihan Guru Implementasi K-13 Tahun 2014. Jakarta: Kemendikbud. (2014).

[7] Meinbach, Antoni Meyer, Liz Rothlein \& Anthony D. Fredericks.. The Complete Guide to Thematic Units: Creating Integrated Curriculum. Norwood: Gordon Publisher. (1995) 
[8] Mulyasa, H.E. Pengembangan dan Implementasi K-13. Bandung: PT Remaja Rosdakarya. (2014).

[9] Nana Syaodih Sukmadinata. Pengembangan Kurikulum: Teori dan Praktek. Bandung: PT Remaja Rosdakarya. (2007).

[10] Peraturan Menteri Pendidikan dan Kebudayaaan nomor 65 tahun 2013 tentang Standar Proses Pendidikan Dasar dan Menengah.

[11] ____. Nomor 67 tahun 2013 Tentang Kerangka Dasar dan Struktur Kurikulum Sekolah Dasar/ Madrasah Ibtidaiyah.

[12] ____. nomor 81 tahun 2013 Tentang Implementasi Kurikulum.

[13] Saifuddin Azwar. Penyusunan Skala Psikologi. Yogyakarta: Pustaka Pelajar. (2015).

[14] Sardiman A.M. Interaksi dan Motivasi Belajar Mengajar. Jakarta: PT Raja Grafindo Persada. (2007).

[15] Schunk, D.H.). Learning Theories: An Educational Perspective (Teori-Teori Pembelajaran: Perspektif pendididikan). Penerjemah: Eva Hamdiah \& Rahmat Fajar. Yogyakarta: Pustaka Pelajar. (2012

[16] Schunk, D.H, Paul R. Pintrich \& Judith L. Meece.. Motivasi dalam Pendidikan : Teori, Penelitian dan Aplikasi. Penerjemah: Ellys Tjo. Jakarta: PT Indeks. (2012)

[17] Syaiful Bahri Djamarah \& Aswan Zain Strategi Belajar Mengajar. Jakarta: Penerbit Rineka Cipta. . (1997).

[18] Sugiyono. Metode Penelitian Pendidikan. Bandung: Penerbit Alfabeta. (2010).

[19]________._Statistika Untuk Penelitian. Bandung: Penerbit Alfabeta. (2010).

[20] Suharsimi Arikunto. Prosedur Penelitian: Suatu Pendekatan Praktik. Jakarta: PT Rineka Cipta. (2006).

[21] Sukardi. Metodologi Penelitian Pendidikan: Kompetensi dan Praktiknya. Jakarta: Penerbit Bumi Aksara (2013). 